ГЕРМАН Е.Є., к.Т.н., доцент, ЛИСАЧЕНКО І.Г., к.Т.Н., доценТ, БЕСПАЛОВ К.І., студент (НТУ “ХПІ”)

\title{
Синтез системи управління сушильною установкою використанням нечіткого контролера 3 самоналаштуванням
} 3

Управління процесом сушіння в барабанній сушильній установці є складним комплексним процесом завдяки його багатофакторності. Тому навіть сьогодення таке управління здійснюється частково на основі класичних методів, а частково за допомогою оператора. В статті запропонована система управління барабанною сушильною установкою з використанням самоналагодженого нечіткого ПІД контролеру.

Ключові слова: барабанна сушильна установка, нечіткій ПІД-контроллер, адаптаційний механізм, масштабний коефіцієнт.

\begin{abstract}
1. Вступ
Моделювання промислових установок, і зокрема барабанних сушильних установок (БСУ), $\epsilon$ трудомістким процесом. Це викликано насамперед нелінійністю процесів, які протікають як в просторі так і за часом. Сушарка барабанна призначена для сушіння сипучих матеріалів топковим газами або підігрітим повітрям конвективним протиточним способом. Сушарка барабанна може забезпечуватися автоматикою контролю та управління температурою, подачі та видачі фракції. Автоматика забезпечує управління обертанням барабанної сушарки і подачею палива для підтримки температурного режиму.

Основним завданням дослідження $€$ розробка самоналагоджувального НЛК, який буде адаптуватись до змін процесу і на виході системи отримувати стійкий сигнал та порівняння двох систем управляння. Першої, яка побудована на основі нечіткого ПІД-контролері 3 самоналаштуванням в контурі із зворотним зв' язком, друга - включає НПІДК з самоналаштуванням в замкнутому і розімкненому контурах (гібридний контур). Рішення даної науково-технічної задачі можна отримати без застосування промислових установок якщо використати експериментальну установку для проведення досліджень для отримання математичної моделі, а потім провести аналіз отриманих результатів за допомогою сучасних апаратних та програмних засобів.

Нечітке логічне управління (НЛУ) поєднує в собі два різні типи інформації: чисельні значення вимірюваних та розрахункових показників 3 одного боку, i лінгвістичні інструкції і описи процесу та алгоритм управління, які виробляє експерт (досвідчений оператор).
\end{abstract}

(C) Е.С. Герман, І.Г. Лисаченко, К.І. Беспалов, 2015

\section{2. Основна частина}

Система нечіткого управління $\epsilon$ експертною системою реального часу, яка реалізовує ту частину системи управління, яка відноситься до досвідченого оператора або спирається на досвід і знання інженератехнолога і не може бути адекватно виражена у вигляді диференціальних рівнянь або через опис параметрів ПІД-управління, але при цьому може бути успішно представлена у вигляді ситуаційних правил дії (situationaction rules).

Нечітка логіка вводить в алгоритм управління елементи людського мислення. У зв'язку 3 цим звичайна математична модель процесу не $\epsilon$ основою для проектування моделей на основі нечіткої логіки. Контролери, які розроблені за цією методикою для реалізації людського мислення, “програмуються" за допомогою мови нечіткої логіки, реалізованої через функції приналежності, правила і їх інтерпретації.

Прикладами використання нечіткої логіки можуть бути наступні системи, в яких використання класичних ПІД-контролерів (КПІДК) не в змозі вирішити деякі технічні завдання з урахуванням наступних чинників [1]:

- Нелінійність об'єкту управління. Ефективні лінійні моделі процесу або контрольованого об'єкту є сильно обмеженими. Крім того, нелінійні моделі потребують від контролера значних розрахункових ресурсів та мають проблеми загальної стійкості системи управління.

- Об'єкт управління знаходиться в стані невизначеності. Тому немає уявлення про його дійсну математичну модель, яка будується за відсутністю повного обсягу інформації.

- Застосування багатовимірних та багатоконтурних систем управління. Такі системи мають комплексні обмеження і взаємозалежності.

- Наявність погрішностей вимірювань. Погрішності вимірювань не завжди можуть бути 
описані стохастичною моделлю шумів.

- Поведінка об'єкту і системи в русі часу. Об'єкт, регулятор, устаткування, зовнішні умови міняються 3 плином часом. Крім того, тимчасові запізнювання важко моделювати.

Перевагами використання нечіткого управління $\epsilon$ наступні аспекти [2]:

- Робастність управління. Нечіткий контролер є більш робастним, ніж класичний, особливо в системах, де параметри класичного регулятора змінюються або основні зовнішні дії призводять до різкого зниження продуктивності. При таких діях, класичне ПІДуправління зазвичай зводиться до компромісу між швидкістю відгуку системи, при збільшенні якого зростає перерегулювання, і сповільненою реакцією, або сама стійкість системи ставиться під питання. В цьому випадку, нечітке управління пропонує прості, але надійні шляхи рішення, які охоплюють широкий спектр параметрів системи і які можуть справитися із значними зовнішніми перешкодами.

- Збільшення ступеня автоматизації. У багатьох випадках технологічних процесів ступінь автоматизації $є$ досить низькою. Нечітке управління пропонує методологію уявлення і реалізації знань досвідченого оператора (експерта) для розширення ступеня автоматизації.

- Зниження витрат на розробку та супровід. Розробити нечіткий контролер дешевше, ніж розробити інший контролер на основі моделі. Такий контролер простий для сприйняття та зручний при зміні своїх правил.

Більшість реальних процесів, які вимагають автоматичного управління, є нелінійними за своєю природою. Тобто, значення параметрів міняються 3 часом залежно від змін робочого режиму. Оскільки класичні алгоритми управління $€$ лінійними, налаштування регулятора може давати хороші показники системи тільки при певному робочому режимі або протягом обмеженого періоду часу. НЛК має нелінійний характер, і тому такий контролер може бути застосований для нелінійного управління процесом. Проте розробка системи управління з НЛК є складним завданням, особливо якщо контролер повинен справлятися 3 нелінійністю протягом значного робочого діапазону процесу. У зв'язку з цим виникає необхідність в адаптації системи управління до зовнішніх i внутрішніх чинників, яки впливають на процес (об'єкт управління).

Відомо [1], що система управління є адаптивною, якщо вона може автоматично змінювати власні параметри, підстроюючись під змінні параметри зовнішніх обставин та самого об'єкту. Так, на рис. 1 показана блок-схема такої системи управління, де для отримання сигналу управління використовується інформація про стан поточного процесу з урахуванням коефіцієнтів коректування, отриманих за допомогою НЛК.

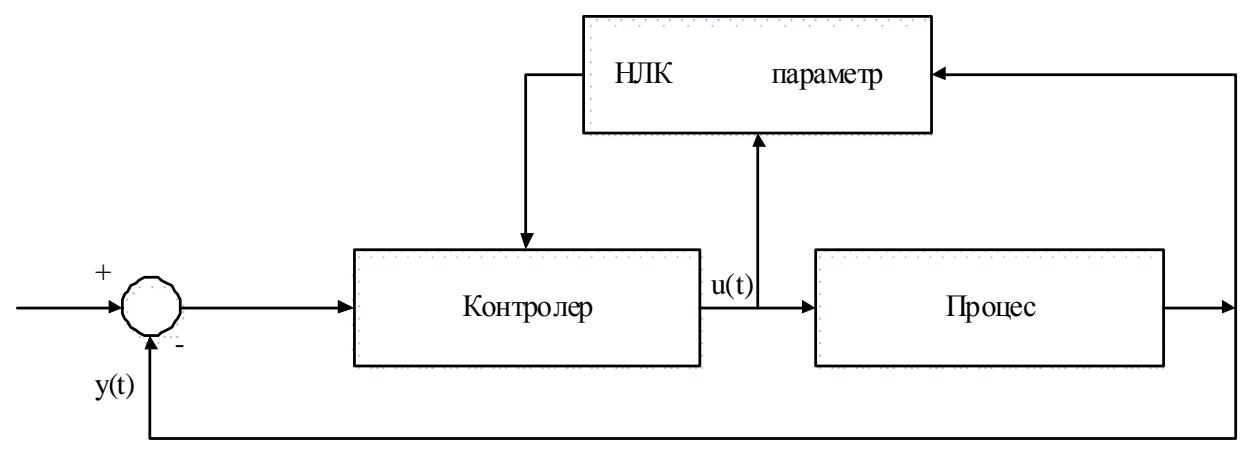

Рис. 1. Адаптивна система управління

Адаптивний ПІД-контролер зазвичай містить дві “надбудови” (додаткові компоненти) до класичного ПІД-контролера. Першим компонентом є пристрій моніторингу процесу управління (ПМПУ), який відстежує зміни в самій системі управління. Другим компонентом $є$ сам адаптаційний механізм, який на основі інформації, що отримує від УМПУ, потім уточнює параметри регулятора. В цілому, використання адаптивного регулятора в системі управління призводить до того, що вона працює в супервізорному режимі (в рамках одного контуру управління). Тобто адаптаційна складова приводить до зміни параметрів ПІД-регулятора. В якості адаптаційного пристрою зручно використовувати НЛК, який містить відповідну кількість наборів параметрів, які можуть бути модифіковані для зміни характеристик самого контролера. До таких параметрів можна віднести:

- $\quad$ коефіцієнт масштабування для кожної змінної;

- нечітка множина, яка визначає лінгвістичне значення;

- правила в нотації "ЯКЩО-ТОДІ". 


\section{3. Розробка адаптивного нечіткого регулятора}

3 проведеного аналізу попередніх праць було запропоновано розробити модель системи управління БСУ яка використовуватиме нечіткий логічний контролер ПІ-типу з самоналаштуванням (СННПІК). За основу була взята модель системи управління, яка була описана в роботі Муді и Пала [3]. Базова ідея їх досліджень була в тому, що досвідчена людинаоператор завжди намагається керувати вхідним сигналом процесі (виходом контролера) шляхом зміни коефіцієнтів (як правило е i $\Delta$ e) за для отримання оптимальної керованості процесу. Тому було запропоновано використовувати тільки налаштування вихідного масштабного коефіцієнту (КМ), як найбільш впливового.

Запропонований контролер настроюється динамічно, налаштовуючи свій вихід КМ в кожен момент вимірювання (такт часу) шляхом оновлення множника $\alpha$. Значення $\alpha$ розраховується за допомогою нечіткої бази правил, які визначені по $e$ та $\Delta e$. Блоксхема такого контролера представлена на рис. 2.

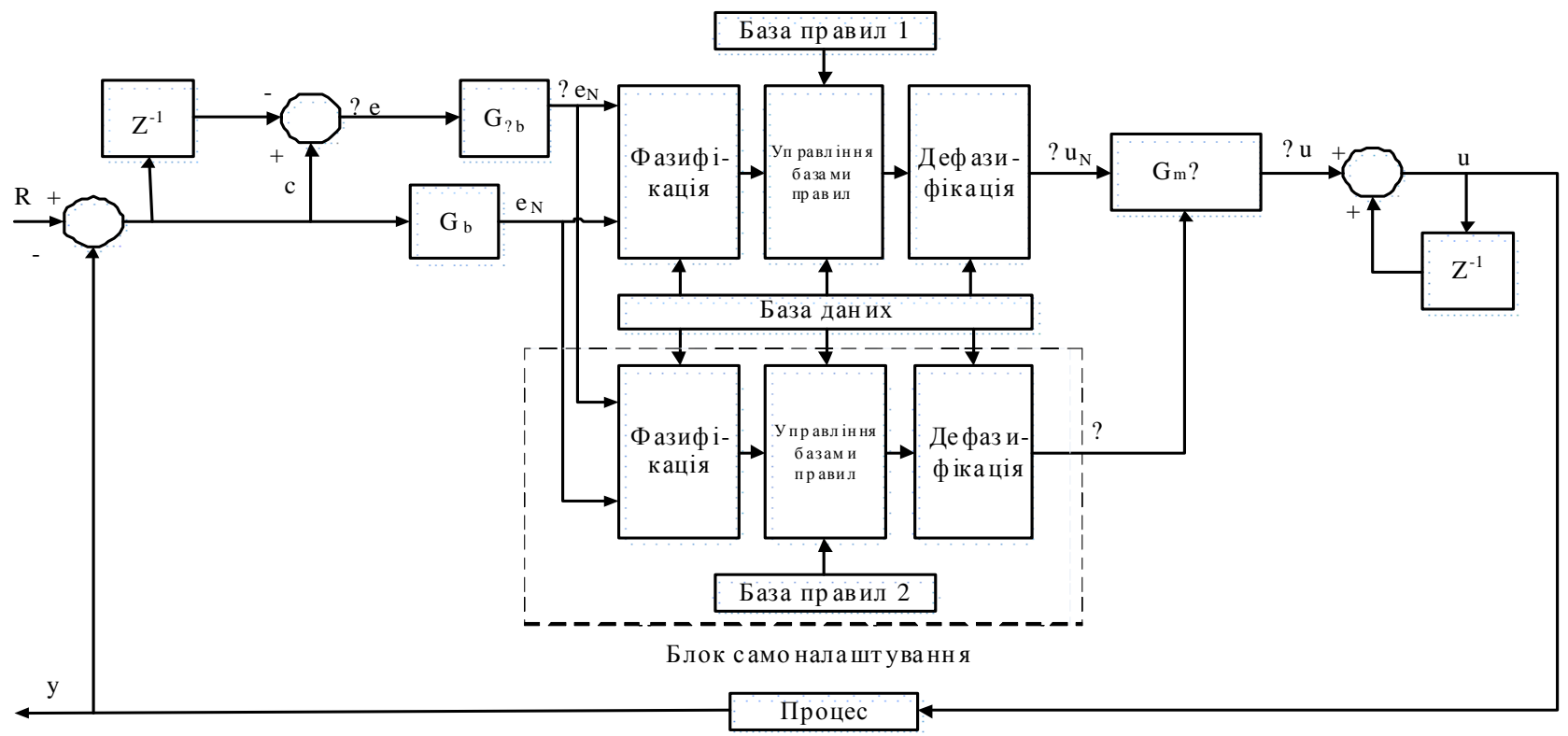

Рис. 2. Нечіткий ПІ контролер з самоналаштуванням (СННПІК)

Вихідний КМ контролера змінюється за нормованій області [-1,1], тоді як ФП для $\alpha$ визначені в допомогою механізму самоналаштування, який позначенній пунктирною лінією на рис. 3. ФП для входу контролера (тобто $e$ i $\Delta e$ ) і інкрементне змінення на виході контролера (тобто $\Delta u$ ) визначені в загальній

нормованій області [0,1]. ФП $є$ рівнобедреними трикутниками $350 \%$ перекриттям, як це показано на рис. 3.
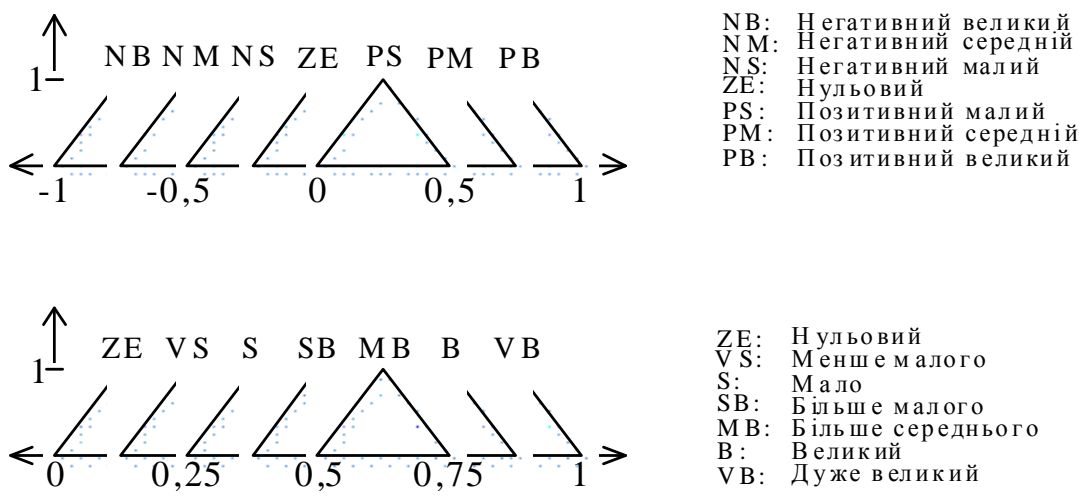

Рис. 3. Функції приналежності 
Математична модель БСУ, яка представлена у другому розділі, була реалізована в пакеті прикладних програм MATLAB на мові візуального програмування Simulink. Алгоритми управління були реалізовані при використанні FuzzyLogicToolbox. Моделювання проводилося на стандартному ПК. Зміна вхідної дії була реалізована ступінчастим сигналом. Результати порівнювалися $з$ аналогічними системами управління на основі КПІДК.

\section{4. Виводи}

У підсумку проведених досліджень потрібно відмітити, що були представлені дві різні системи управління. Перша система була побудована на нечіткому ПІД-контролері 3 самоналаштуванням в контурі із зворотним зв'язком, друга - включає НПІДК 3 самоналаштуванням в замкнутому і розімкненому контурах (гібридний контур). Обидві системи управління дають кращі результати, ніж система 3 КПІДК. Особливо це стосується гібридного контролера, коли ступінчасте обурення йде по каналу вологості твердих фракцій. Його ефективність незначно знижується в присутності вторинних збурень.

\section{Література}

1. Загарий Г.И. Программируемые контролеры для систем управления. Часть 1. Архитектура и технология применения / Г.И. Загарий, Н.О. Ковзель, В.И. Поддубняк и др. - Харьков: ХФИ “Транспорт Украины”; - Харьков: Издательство “Регион Информ”, 2001. - 316 с.

2. Герман Э.Е. Современное состояние и перспективы развития систем нечеткого управления / Э.Е. Герман // Вісник НТУ “ХПІ". 2008. - №57. - C.37-44.

3. Mudi R.K. A robust self-tuning scheme for PI and PD type fuzzy controllers / Mudi R.K., Pal N.R. // IEEE Transactions on Fuzzy Systems. - 1999. - Vol. 7. P 2-16.
Герман Э.Е., Лисаченко И.Г., Беспалов К.И. Синтез системы управления сушильной установки с использованием нечеткой контроллер с самонастройка. Управление процессом сушки в барабанной сушильной установке вследствие своей многофакторности является сложным комплексным процессом. Поэтому даже в настоящее время такое управление осуществляется частично на основе классических методов, а частично с помощью оператора. В статье предложена система управления барабанной сушильной установкой с использованием нечеткого контроллера ПИД с самонастройкой.

Ключевые слова: барабанная сушильная установка, нечеткий ПИД-контроллер, адаптационный механизм, масштабный коэффициент.

German E.E., Lisachenko I.G., Bespalov K.I. The synthesis of a drying unit control system using a fuzzy controller with self-adjustment. The control of the drying process in a drum-type drying unit due to its multifactorial nature is a difficult and complex process. Therefore, even at present such control is partially maintained on the basis of classical techniques and partially with the help of operator. The paper proposes a drum-type drying unit control system using a fuzzy self-adjusting PID controller.

Key words: drum-type drying unit, fuzzy PID controller, adaptive mechanism, the scaling factor.

Рецензент Подустов М.О., д.т.н., професор (НТУ “ХПІ”)

Поступила 21.12.20142 